\title{
Prostaglandin $\mathrm{F}_{2 \alpha}$ のラットの黄体血管及び黄体機能に対する作用
}

\author{
松本公一郎・松尾三郎・酒井利孝・津田 健・ \\ 柴田邦治・䅖本 晃・無量林堯 \\ (小野薬品工業株式会社 中央研究所)
}

ラット ${ }^{1)}$ や羊 $^{2)}$ その他多くの動物において, prostaglandin $\mathrm{F}_{2 \alpha}\left(\mathrm{PGF}_{2 \alpha}\right)$ が黄体退化作用を有することはよ く知られているが，そのメカニズムについて定説はな い。 MCCRACKEN ら ${ }^{3,4)}$ は, $\mathrm{PGF}_{2 \alpha}$ が子宮から分泌され て黄体に作用する機序は, 子宮静脈一卵巣動脈間の counter-current diffusion によると説明した。一方,

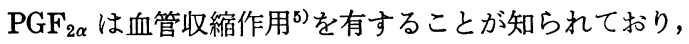
畉巣動脈 あるいは子宮静脈-卵巣動脈の収縮作用による 血流の減少作用が黄体退化作用と関連して考えられるよ らになった。PHARRISS ら ${ }^{6)}$ は卵巣の血流量が, GODING $ら^{7)}$ 及び Novy $5^{8)}$ は黄体血流量の減少が黄体退化の原 因であることを示唆し，BEHRMAN ら ${ }^{9)}$ は卵巣で JANSON $ら^{10)}$ は黄体での血流量に影響なく progesterone $(\mathrm{P})$ 分 泌を抑制したといら相反する報告がある。

著者らは，本報において microangiography による 外因性 $\mathrm{PGF}_{2 \alpha}$ 及び noradrenaline (NA) の黄体血管に 対する作用を観察し, 黄体機能との相互の関連性につい て考察したので報告する。

\section{実験材料及び方法}

供試動物は生後 8 週令の未経産 Wistar 系ラットであ る。これを同系雄ラットと交配させ, 腟スメアー中に精 子を認めた日を妊娠 0 日目として妊娠 17 日目に実験に 供した。 $\mathrm{PGF}_{2 \alpha}$ (小野薬品) は $50 \mathrm{mM}$ リン酸緩衝液 $(\mathrm{pH}$ .4）に溶解して，NAはノルアドリナリン® (三共)を 生理食塩液で希釈して使用した。

\section{1. 黄体の微小血管に対する作用}

ウレタン麻酔下で開腹し, 消化管及び子宮を体外に引 き出して腹部大動脈を露出し, 腹腔内に温めた生理食塩

The effect of prostaglandin $\mathrm{F}_{2 \alpha}$ on luteal microvasculature and luteal function in rats.

Matsumoto, Kimiichiro, Saburo Matsuo, Toshitaka SakaI, Takeshi Tsuda, Kuniharu Shibata, Akira Aкiмото, \& Takashi Muryobayashi (Research Institute, Ono Pharmaceutical Co. Ltd., 3-1-1, Sakurai, Shimamoto-cho, Mishima-gun, Osaka 618) Japan. J. Anim. Reprod. 24 (1), 1678.

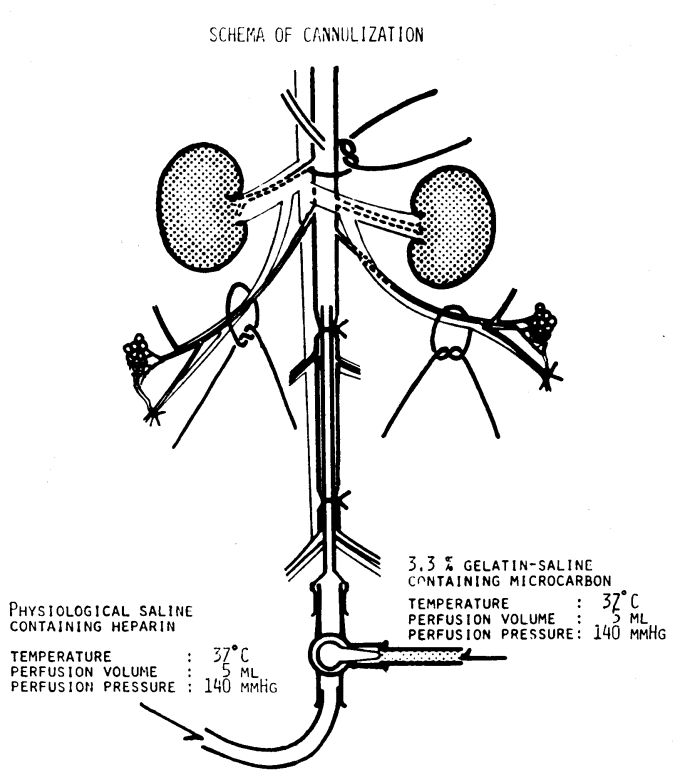

Fig. 1. Schema of cannulization in microangiography.

液を満たした。図 1 に示すように子宮と卵巣を切り離 し, 左卵巣の動静脈に糸をかけておく。大動脈は右腎動 脈直下, 左卵巣動脈より約 $1.5 \mathrm{~cm}$ 下及び約 $3 \mathrm{~cm}$ 下を静 脈と分離し糸をかけ，カニューレ(金属製内径 $0.7 \mathrm{~mm}$ ) を挿入した。卵巣の灌流は, 頸部静脈の切開之同時に右 腎動脈直下の大動脈を結禁し, 直ちにヘパン (250 U/ $\mathrm{ml}$ ) を含む生理食塩液 $\left(37^{\circ} \mathrm{C}\right) 5 \mathrm{ml}$ をカニューレを介し て注入した後, 直ちに微小炭末を含む $5 \%$ ゼラチン・ 生理食塩液 $\left(37^{\circ} \mathrm{C}\right) 5 \mathrm{ml}$ を注入することによって行っ た。注入圧は, 注入ポンプとカニューレの間に設置した 水銀マノメーターにより 130 140 mmHg で一定になる ようにした。注入が終わると圧がかかった状態で左卵巣 動静脈を結禁して卵巣を取り出した。卵巣は直ちに 0 $5^{\circ} \mathrm{C}$ の生理食塩液に浸し, 約 2 時間後, 周囲の脂肪を除 去し $5^{\circ} \mathrm{C}$ に冷した Bouin 液に浸して冷蔵庫中に 24 時間 放置した。その後常法に従ってパラフィン包埋を行い, 
$20 \mu$ の透徹切片を作製し 顕微鏡にて 黄体内の微小血管 像を観察した。

黄体内の微小血管状態の指標としては, 微小炭末で内 部を充満した 血管の太さ及び 網目状構造の 状態を 観察 し，次の四段階の評価を行った (Plate 1)。

卅：黄体全体の 毛細血管は口径が $9 \sim 11 \mu$ の太いも のが支配的で鮮明な微小炭末分布の網目状構造が認 められる (No. 1)

H: 黄体全体の毛細血管は口径が $2 \sim 2.5 \mu$ の細いも のが支配的で鮮明な網目状構造が認められる（No. 2)

+ : 網目構造が部分的に途切れを生じ不鮮明になって いる (No. 3)

\pm : 黄体全体の網目状構造がくずれ, 断片的な血管像 しか認められない (No. 4)

薬物は, 卵巣灌流を行ら 60 秒前 $\left(\mathrm{PGF}_{2 \alpha}\right)$ または 30 秒前 (NA) に頸部静脈内に投与した。

\section{2. 全身血圧に対する作用}

ウレタン麻酔下で頸動脈にポリエチレンカテーテルを 挿入，圧トランスジューサー（MP-24-S，日本光電）を 介して, 平均血圧をポリグラフ (RM-85, 日本光電) に 記録した。薬物は尾静脈及び背部皮下に投与した。

\section{3. 胎仔に及ぼす影響}

妊娠 17 日目の 10 時及び 16 時に $\mathrm{PGF}_{2 \alpha}$ または $\mathrm{NA}$ を
ラット尾静脈あるいは背部皮下に投与し，妊娠 20 日目 に全てのラットを屠殺剖検して, 子宮重量, 着床数, 生 胎仔数を調べた。各母体の総着床数から生胎仔数を差引 いた数を整死胎仔数（流産胎仔数十子宮内死胎仔数）之 し，総着床数に 対する百分比をもって胎仔整死率とし た。

\section{実験結果}

\section{1. 黄体の微小血管に対する作用}

(1) 妊娠黄体の微小血管像 (Plate II)：炭末分布か ら観察されるラットの妊娠黄体の微小循環は, 卵巣動脈 から分かれ，黄体周囲に分布した小動脈からさらに枝分 かれして黄体表面の結合組織を貫き，黄体内に入り込ん だ多数の細動脈により灌流されている。この細動脈はす ぐに分散し, 毛細血管として黄体細胞を包囲しながら迁 曲し網目状の毛細血管網を形成する。黄体細胞からのこ の毛細血管網は黄体中心に向って進み，中心にある集合 静脈に合流し黄体外に出る (No. 5)。無処置群は 7 頭の 妊娠ラットから得た 39 個の黄体について観察した。そ の結果，表 1 に示すように, 36 個 $(92.3 \%)$ の黄体には 鮮明な網目状構造が観察され，その内の 27 個 $(69.2 \%)$ の黄体の毛細血管は口径が 9 11 $\mu$ の太いものが 支配的 であった (No. 5)。

（2） NA による影響：NA を黄体灌流の 30 秒前に投

Table 1. Effect of prostaglandin $\mathrm{F}_{2 \alpha}\left(\mathrm{PGF}_{2 \alpha}\right)$ and noradrenaline (NA) on microvasculature of corpus luteum (CL) of rats

\begin{tabular}{|c|c|c|c|c|c|c|c|}
\hline \multicolumn{2}{|l|}{ Groups } & \multirow{2}{*}{$\begin{array}{c}\begin{array}{c}\text { No. of } \\
\text { animals }\end{array} \\
7\end{array}$} & \multirow{2}{*}{$\begin{array}{c}\begin{array}{c}\text { No. of CL } \\
\text { observed }\end{array} \\
39\end{array}$} & \multicolumn{4}{|c|}{ No. of CL microvascularized as stages $(\%)$} \\
\hline Control & & & & $\begin{array}{l}27 \\
(69.2)\end{array}$ & $\begin{array}{c}9 \\
(23.1)\end{array}$ & $\begin{array}{l}2 \\
(5.1)\end{array}$ & $\begin{array}{l}1 \\
(2.6)\end{array}$ \\
\hline \multirow{2}{*}{ NA } & $10 \mu \mathrm{g} / \mathrm{kg}$ & 5 & 27 & \multirow{2}{*}{$\begin{array}{c}8 \\
(29.6) \\
1 \\
(3.8)\end{array}$} & \multirow{2}{*}{$\begin{array}{c}9 \\
(33.3) \\
6 \\
(23.1)\end{array}$} & \multirow{2}{*}{$\begin{array}{c}5 \\
(18.5) \\
7 \\
(26.9)\end{array}$} & \multirow{2}{*}{$\begin{array}{c}5 \\
(18.5 \\
12 \\
(46.2\end{array}$} \\
\hline & $50 \mu \mathrm{g} / \mathrm{kg}$ & 5 & 26 & & & & \\
\hline \multirow{3}{*}{$\mathrm{PGF}_{2 \alpha}$} & $50 \mu \mathrm{g} / \mathrm{kg}$ & 5 & 22 & \multirow{3}{*}{$\begin{array}{l}0 \\
\left(\begin{array}{l}0 \\
1\end{array}\right) \\
(3.7) \\
3 \\
(13.6)\end{array}$} & \multirow{3}{*}{$\begin{array}{c}12 \\
(54.5) \\
9 \\
(33.3) \\
2 \\
(9.1)\end{array}$} & \multirow{3}{*}{$\begin{array}{c}6 \\
(27.3) \\
13 \\
(48.2) \\
11 \\
(50.0)\end{array}$} & \multirow{3}{*}{$\begin{array}{c}4 \\
(18.2) \\
4 \\
(14.8) \\
6 \\
(27.3)\end{array}$} \\
\hline & $125 \mu \mathrm{g} / \mathrm{kg}$ & 5 & 27 & & & & \\
\hline & $250 \mu \mathrm{g} / \mathrm{kg}$ & 5 & 22 & & & & \\
\hline
\end{tabular}

Four stages of luteal microvasculature.

H: a multitude of thick microvasculature $(9 \sim 11 \mu$ in diameter $)$ is observed as a whole, and the network is clear (Photo 1 ).

H: a multitude of thin microvasculature $(2 \sim 2.5 \mu$ in diameter $)$ is observed as a whole, and the network is clear (Photo 2).

+ : the network is partially broken and obscure (Photo 3).

\pm : a broken network is observed, and the fragmental vessels only are observed in corpus luteum (Photo 4). 
与した場合，黄体の微小循環障害を示唆する次のごとき 成績（表 1) が得られた。すなわち，10 $\mu \mathrm{g} / \mathrm{kg}$ の投与 では， 5 頭の動物から得た 27 個の黄体中 17 個 $(62.9$ $\%$ ）に明膫な網目状構造が観察され，その内 8 個 (29.6 \%) は太い毛細血管が支配的であり，9個は細い毛細血 管が支配的であった (No. 6)。他の 10 個 (37\%) の黄 体には網目状構造のくずれ（部分的： $18.5 \%$, 全体的: $18.5 \%)$ が観察され, 無処置と比較すると明らかな差が みられた。 $50 \mu \mathrm{g} / \mathrm{kg}$ 投与では, 網目状構造のくずれが 增強した。つまり 5 頭の動物から得た 26 個の黄体中 19 個 $(73 \%)$ に網目状構造のくずれが全体的に観察され, その内の 12 個 (46.2\%) は，ほとんぞの毛細血管が点 状にしかみえないものもあった（No. 7)。

(3) $\mathrm{PGF}_{2 \alpha}$ による影響: $\mathrm{PGF}_{2 \alpha}$ を黄体灌流の 1 分前 に静脈内投与した場合, 表 1 に示すように用量に応じた 黄体の微小循環の抑制が認められた。 $\mathrm{PGF}_{2 \alpha} \quad 50 \mu \mathrm{g} / \mathrm{kg}$ 投与では, 5 頭の妊娠ラットから得た 22 個の黄体中 12 個 $(54.5 \%)$ は細い $(2 \sim 2.5 \mu)$ 毛細血管が支配的であ りながら鮮明な網目状構造が観察された（No. 8) が， 他の 6 個 $(27.3 \%)$ は部分的， 4 個 $(18.2 \%)$ は全体的 に炭末分布の網目状構造のくずれが観察された。また $\mathrm{PGF}_{2 \alpha} 125 \mu \mathrm{g} / \mathrm{kg}$ では 5 頭の動物から得た 27 個の黄体 中 17 個 (63\%) に網目状構造のくずれ（部分的： $48.2 \%$, 全体的: 14.8\%) が観察された (No. 9)。250 $\mu \mathrm{g} / \mathrm{kg}$ 投 与ではさらにその率が増加し 5 頭から得た 22 個の観察 黄体中 17 個 $(77.3 \%)$ 飞網目状構造のくずれ（部分的： $50 \%$, 全体的: $27.3 \%$ ) が観察された (No. 10)。

\section{2. 全身血圧に対する作用}

$\mathrm{PGF}_{2 \alpha}$ は頸動脈圧に対して二相性または三相性の変 化を示した。すなわち， $5 \mu \mathrm{g} / \mathrm{kg}$ (約最小作用量) 100 $\mu \mathrm{g} / \mathrm{kg}$ の投与量では一過性の下降後, 上昇作用が認めら れた。

$\mathrm{NA}$ は 0.5 50 $\mu \mathrm{g} / \mathrm{kg}$ の投与量によって $2 \sim 5$ 分間持 続する上昇作用を示した。

皮下投与においては， $\mathrm{PGF}_{2 \alpha}$ 及び NA はいずれも 1 $\mathrm{mg} / \mathrm{kg}$ で同程度の血圧上昇作用を示した。

\section{3. 胎仔に及ばす影響}

静脈内投与では $\mathrm{PGF}_{2 \alpha}(250 \mu \mathrm{g} / \mathrm{kg})$ 及び NA $(50 \mu \mathrm{g} /$ $\mathrm{kg}$ ）の両投与群とも胎仔に影響を及ぼさなかった。一 方，皮下投与では $\mathrm{PGF}_{2 \alpha} 250 \mu \mathrm{g} / \mathrm{kg}$ 以上の投与群に掠 いて著明な胎仔整死を認めた。250, 500 及び $1000 \mu \mathrm{g} / \mathrm{kg}$ の投与群はそれぞれ $77.3,83.8$ 及び $100 \%$ と高い胎仔 擎死率を示し, 子宮重量も有意に軽かった。NA 投与群 では, $1000 \mu \mathrm{g} / \mathrm{kg}$ でもほとんど胎仔の獘死を認めなか った（表 2 )。

\section{考察}

$\mathrm{PGF}_{2 \alpha}$ は動物において黄体退化作用を有するが，そ の機構についての定説はない。著者らは, 報告者によっ て必ずしも一致した結果をみない黄体循環に対する作用 について, microangiography による炭末分布を顕微鏡 的に観察することによって黄体の微小血管に対する作用 を追究した。その結果, $\mathrm{PGF}_{2 \alpha}$ は $50 \sim 250 \mu \mathrm{g} / \mathrm{kg}$ の静 脈内投与で用量に応じた黄体血管収縮作用を示し，NA

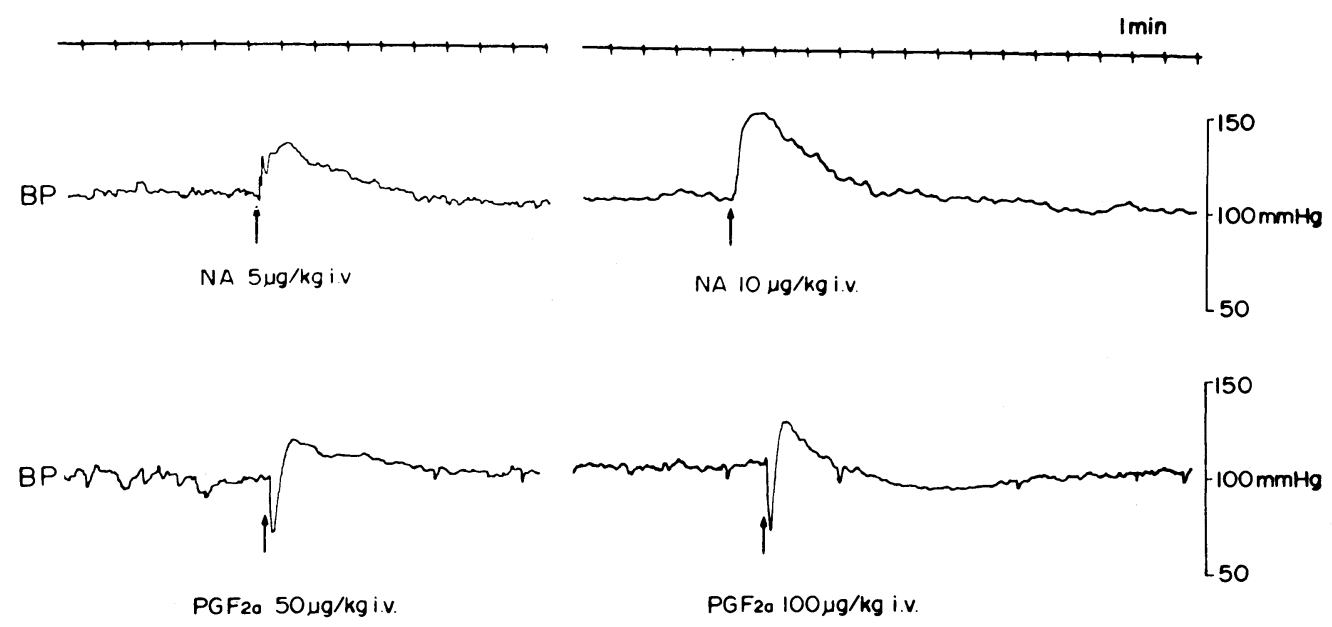

Fig. 2. Effects of prostaglandin $\mathrm{F}_{2 \alpha}\left(\mathrm{PGF}_{2 \alpha}\right)$ and noradrenaline (NA) on arterial blood pressure in rats. 
Table 2. Effects of prostaglandin $F_{2 \alpha}$ and noradrenaline on fetal mortality, administered in rats at day 17 of pregnancy (sacrificed on day 20)

\begin{tabular}{|c|c|c|c|c|c|}
\hline Groups & $\begin{array}{l}\text { Doses } \\
(\mu \mathrm{g} / \mathrm{kg}, \quad \text { b. i. d. })\end{array}$ & route & $\begin{array}{l}\text { No. of } \\
\text { effective } \\
\text { cases/No. } \\
\text { treated }\end{array}$ & $\begin{array}{l}\text { Mortality } \\
\text { rate }(\%)\end{array}$ & $\begin{array}{l}\text { Total fetal weight } \\
\text { in uterus } \\
(\mathrm{g}) \\
\text { Mean } \pm \text { S.E. }\end{array}$ \\
\hline Control & Vehicle & sc & $0 / 4$ & 6.6 & $61.7 \pm 5.6$ \\
\hline Noradrenline & $\begin{array}{r}50 \\
10,000\end{array}$ & $\begin{array}{l}\text { iv } \\
\text { sc }\end{array}$ & $\begin{array}{l}0 / 5 \\
0 / 5\end{array}$ & $\begin{array}{l}0 \\
1.9\end{array}$ & $\begin{array}{l}63.2 \pm 2.8 \\
58.0 \pm 4.4\end{array}$ \\
\hline Prostaglandin $\mathrm{F}_{2 \alpha}$ & $\begin{array}{r}250 \\
100 \\
250 \\
500 \\
1,000\end{array}$ & $\begin{array}{l}\text { iv } \\
\text { sc } \\
\text { sc } \\
\text { sc } \\
\text { sc }\end{array}$ & $\begin{array}{l}0 / 5 \\
0 / 5 \\
5 / 9 \\
7 / 9 \\
4 / 4\end{array}$ & $\begin{array}{c}0 \\
5.8 \\
77.3 \\
83.8 \\
100\end{array}$ & $\begin{array}{c}58.0 \pm 4.4 \\
62.2 \pm 8.0 \\
23.3 \pm 7.4^{*} \\
15.6 \pm 8.0^{*} \\
3.6 \pm 1.5^{*}\end{array}$ \\
\hline
\end{tabular}

* Significantly different from control, $\mathrm{p}<0.05$

The 'effective cases' referred to those retained no live fetuses regardless of dead fetuses in the same uterus.

Abortion rate shows the proportion of the aborted and resorbing conceptuses to the implanted ones.

も $10 \sim 50 \mu \mathrm{g} / \mathrm{kg}$ で同様な作用を示した。この収縮作用 の強度は, $\mathrm{PGF}_{2 \alpha} 50 \mu \mathrm{g} / \mathrm{kg}$ ならびに NA $10 \mu \mathrm{g} / \mathrm{kg}$ の 投与量においてほぼ等しい結果であったが, 頸動脈圧の 上昇作用は NA の方が強いように見受けられた。また $\mathrm{PGF}_{2 \alpha}$ の末梢血管収縮作用が，NA に比較して黄体血管 で高度に特異的であるとは思われなかった。

本実験に打いて，妊娠 17 日目の無処置ラットの黄体 は豊富な微小循環網を持つことが明らかとなったが，こ の部位における毛細血管の発達と十分な血液循環が，黄 体細胞への $\mathrm{O}_{2}$ やステロイド前駆物質の供給, 黄体細胞 から標的臟器へのステロイドホルモンの分泌などのため に重要であろらと推察される。ABDUL-KARIM ら ${ }^{11)}$ も, ウサギに怙いて妊娠 $16 \sim 20$ 日目の黄体血流量は最大と なり, progesterone 分泌の極期と一致するため，増加 した血流量が活発なステロイド生合成と関係あるのでは ないかと示唆しているように，黄体細胞一の血流の持続 的減少は黄体機能の低下につながるかも知れない。

著者ら ${ }^{12,13)}$ は，ラットにおける $\mathrm{PGF}_{2 \alpha}$ の胎仔の整死 や分婏誘発作用は黄体退化作用の結果起こるものと考兄 ているので, 本報においては黄体機能を知る一指標とし て妊娠 17 日目投与が胎仔に及ぼす影響についても観察 したところ， $\mathrm{PGF}_{2 \alpha}$ または $\mathrm{NA}$ の静脈内投与では, 黄 体血管を収縮させた量の 2 回投与 ( 6 時間間隔) によっ ていずれも胎仔の慜死を認めなかった。そこで, 静脈内 投与より持続性が期待できる皮下投与によって，同程度

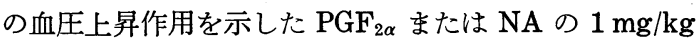
を 2 回投与 (6 時間間隔) したところ， $\mathrm{PGF}_{2 \alpha}$ は $100 \%$ の胎仔整死率を示したのに反し，NA は全く作用を示さ

\section{なかった。}

本実験は黄体血管収縮作用と黄体機能との相互関係を 推察するにはな打不十分であるが，上記の結果や，in vitro においても $\mathrm{PGF}_{2 \alpha}$ が progesterone 合成の低下を 招く ${ }^{14,15)}$ ことなどから， $\mathrm{PGF}_{2 \alpha}$ による黄体血管収縮作 用は黄体退化作用の主因として結びつかない単なる血管 に対する薬理作用であるかも知れない。この薬理作用 が, 黄体退化の一要因となりらるか否かは今後に残され た問題である。

\section{要 約}

妊娠 17 日目のラットを用い, microangiography に よって黄体の微小血管に対する $\mathrm{PGF}_{2 \alpha}$ の作用を検討 し，次の知見を得た。

1. 黄体の微小血管に対し, $\mathrm{PGF}_{2 \alpha}$ は 50,125 及び $250 \mu \mathrm{g} / \mathrm{kg}$ (iv) により用量に応じた著明な収縮作用を示 寸所見が認められた。noradrenaline (NA) では，10 及 び $50 \mu \mathrm{g} / \mathrm{kg}$ (iv) により同様な変化が認められた。

2. 全身血圧に対し，静脈内投与では $\mathrm{PGF}_{2 \alpha}$ の 5 $100 \mu \mathrm{g} / \mathrm{kg}$, NA の $0.5 \sim 50 \mu \mathrm{g} / \mathrm{kg}$ で上昇作用が認めら れた。皮下投与では, 両者とも $1 \mathrm{mg} / \mathrm{kg}$ で血圧上昇作 用が認められた。

3. 胎仔に及ぼす影響について, $\mathrm{PGF}_{2 \alpha} 250 \mu \mathrm{g} / \mathrm{kg}$ 及 び NA $50 \mu \mathrm{g} / \mathrm{kg}$ の静脈内投与 (b. i. d.) によってい ずれも胎仔の整死を認めなかった。一方，皮下投与 (b. i. d.) に㨟いては, $\mathrm{PGF}_{2 \alpha} 1 \mathrm{mg} / \mathrm{kg}$ によって $100 \%$ の 胎仔整死率が認められたが，同量の NA では認められな かった。 
1978 年 3 月

以上の結果は， $\mathrm{PGF}_{2 \alpha}$ 及び NA が，いずれも著明に 黄体の微小循環を抑制するのに対し，黄体機能の低下は $\mathrm{PGF}_{2 \alpha}$ によってのみ見られることを示すものである。

稿を終わるにあたり，御校閲をいただきました大阪府 立大学雚守龍雄教授に深射いたします。

(1977. 8. 1 受付)

\section{文献}

1) Pharriss, B. B. \& L. J. Wyngarden: Proc. Soc. Exp. Biol. Med. 130, 92, 1969.

2) McCracken, J.A., M. E., Glew \& R. J. Scaramuzzi: J. Clin. Endocrinol. Metab. 30, 544, 1970.

3) McCracken, J.A., J. C. Carlson, M. E. Glew, J.R., Goding, D. T. Baird, K. Green \& B. Samuelsson: Nature New Biol. 238, 129, 1972.

4) Mc Cracken, J.A.: Ann. NY Acad. Sci. 180, 456, 1971.

5) DuCharme, D. W., J.R. Weekes \& R.G. Montgomery: J. Pharm. Exple. Therapeut. 160, 1, 1968.

\section{家畜繁殖誌 24 巻 1 号}

6) Pharriss, B. B. \& L. J. Wyngarden: Proc. Soc. Exptl. Biol. Med. 130, 92, 1969.

7) Goding, J. R., D. T. BAIRd, I. A. Gumming \& J. A. McCracken: Acta Endocrinol. (Suppl.) 158, 169, 1972.

8) Novy, M. J. \& M. J. Cook: Am. J. Obstet. Gynecol. 117, 381, 1973.

9) Behrman, H.R., K. Yoshinaga \& R. O. GreeP: Ann. NY Acad. Sci. 180, 426, 1970.

10) Janson, P.O., I. Albrecht \& K. Ahren: Acta Endocrinol. 79, 337, 1975.

11) Abdul-Karim, R. W. \& N. Bruce: Fert. Ster. 24, 44, 1973.

12) 松本 (公) - 柴田 (邦) - 酒井 (利) - 津田 (健) - 杉山 (正) - 佐藤 (恵) - 藤田 (常)：応用薬理 10,753 , 1975.

13) 松本 (公) - 酒井 (利) - 津田 (健) - 小出 (達) - 稳本 (晃) - 西垣 (善) - 柴田 (邦)：家畜繁殖誌 $24(2)$, 印刷中.

14) O'Grady, J. P., E. I. Kohorn, R. H. Glass, B. V. Caldwell, W. A. Brock \& L. Speroff: J. Reprod. Fert. 30, 153, 1972.

15) McNatty, K. P., K. M., Henderson, \& R. S. SAMERS: J. Endocrinol. 67, 231, 1975.

\section{Summary}

Using rats on day 17 of pregnancy, the effect of prostaglandin $\mathrm{F}_{2 \alpha}\left(\mathrm{PGF}_{2 \alpha}\right)$ on luteal vasculature was investigated with the technique of microangiography.

1. After intravenous administration of $\mathrm{PGF}_{2 \alpha}$ in doses of $50,250 \mu \mathrm{g} / \mathrm{kg}$ as a single injection, remarkable constriction of luteal vasculature was observed dose-dependently. The similar response was caused by noradrenaline (NA) in doses of 10 and $50 \mu \mathrm{g} / \mathrm{kg}$.

2. When $\mathrm{PGF}_{2 \alpha}$ with doses of 5 to $100 \mu \mathrm{g} / \mathrm{kg}$ and $\mathrm{NA}$ of 0.5 to $50 \mu \mathrm{g} / \mathrm{kg}$ were administered, a rise in blood pressure were observed. Subcutaneous administration of $\mathrm{PGF}_{2 \alpha}$ or NA $1 \mathrm{mg} / \mathrm{kg} \mathrm{had}$ also similar response on blood pressure.

3. Intravenously administered $\mathrm{PGF}_{2 \alpha} 250 \mu \mathrm{g} / \mathrm{kg}$ and $\mathrm{NA} 50 \mu \mathrm{g} / \mathrm{kg}$ (b. i.d.) had no effect on fetal mortality in rats. Whereas $\mathrm{PGF}_{2 \alpha} 1.0 \mathrm{mg} / \mathrm{kg}$ (b. i. d.) administered subcutaneously was enough to induce fetal mortality in a all animals, but the same dose of NA was not.

In present report, it is suggested that $\mathrm{PGF}_{2 \alpha}$ and $\mathrm{NA}$ suppress the luteal circulation remarkably but $\mathrm{PGF}_{2 \alpha}$ only plays a role in reduction of luteal function. 
PLATE I

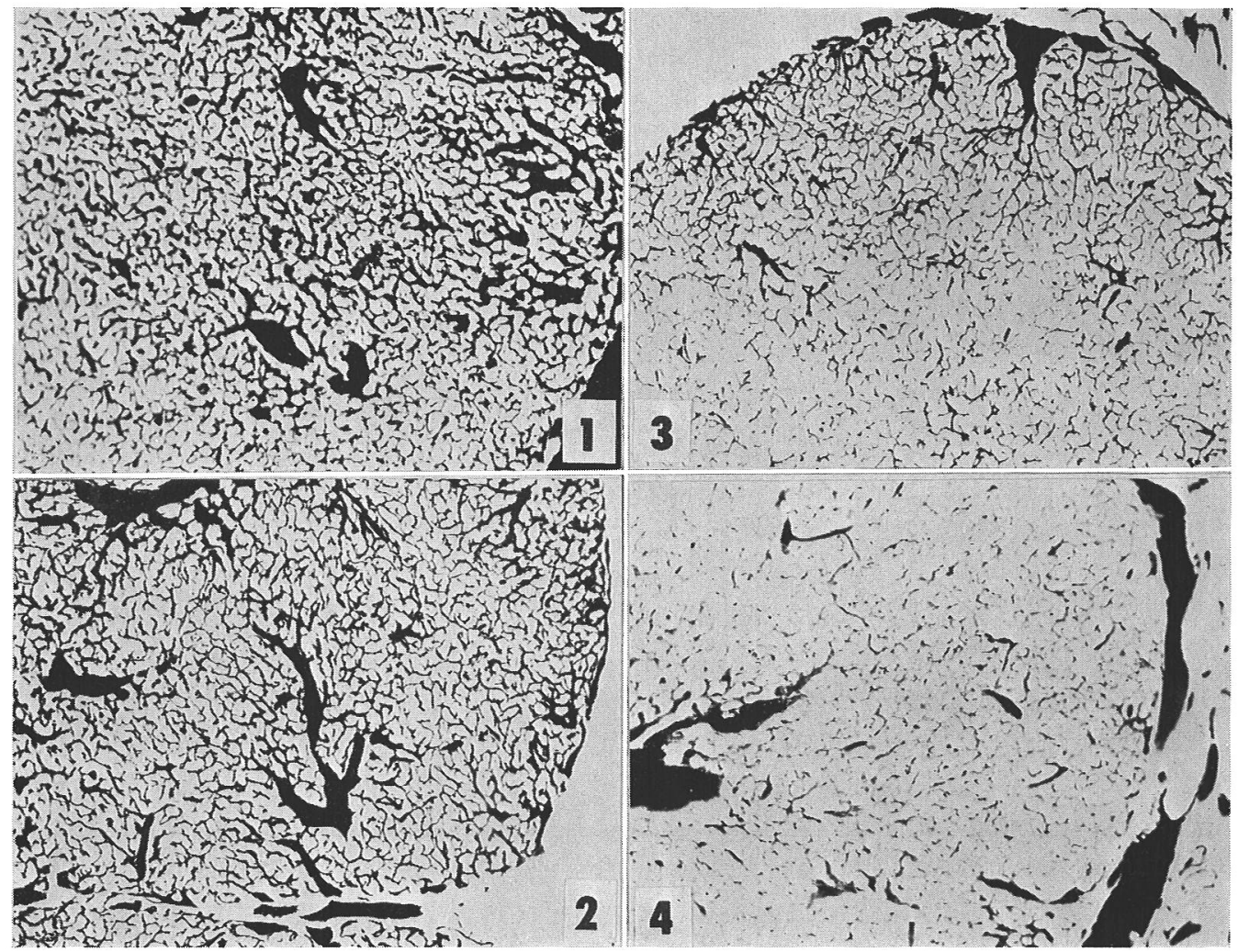

Plate I. Comparative diagrammatic presentation of luteal microvasculature.

No. $1(+$ ) : a multitude of thick microvasculature as a whole, and clear network.

No. 2 (H): a multitude of thin microvosculature as a whole, and clear network.

No. $3(+)$ : partially broken and obscure network.

No. $4( \pm)$ : a broken network and fragmental vessels only. 


\section{PLATE II}
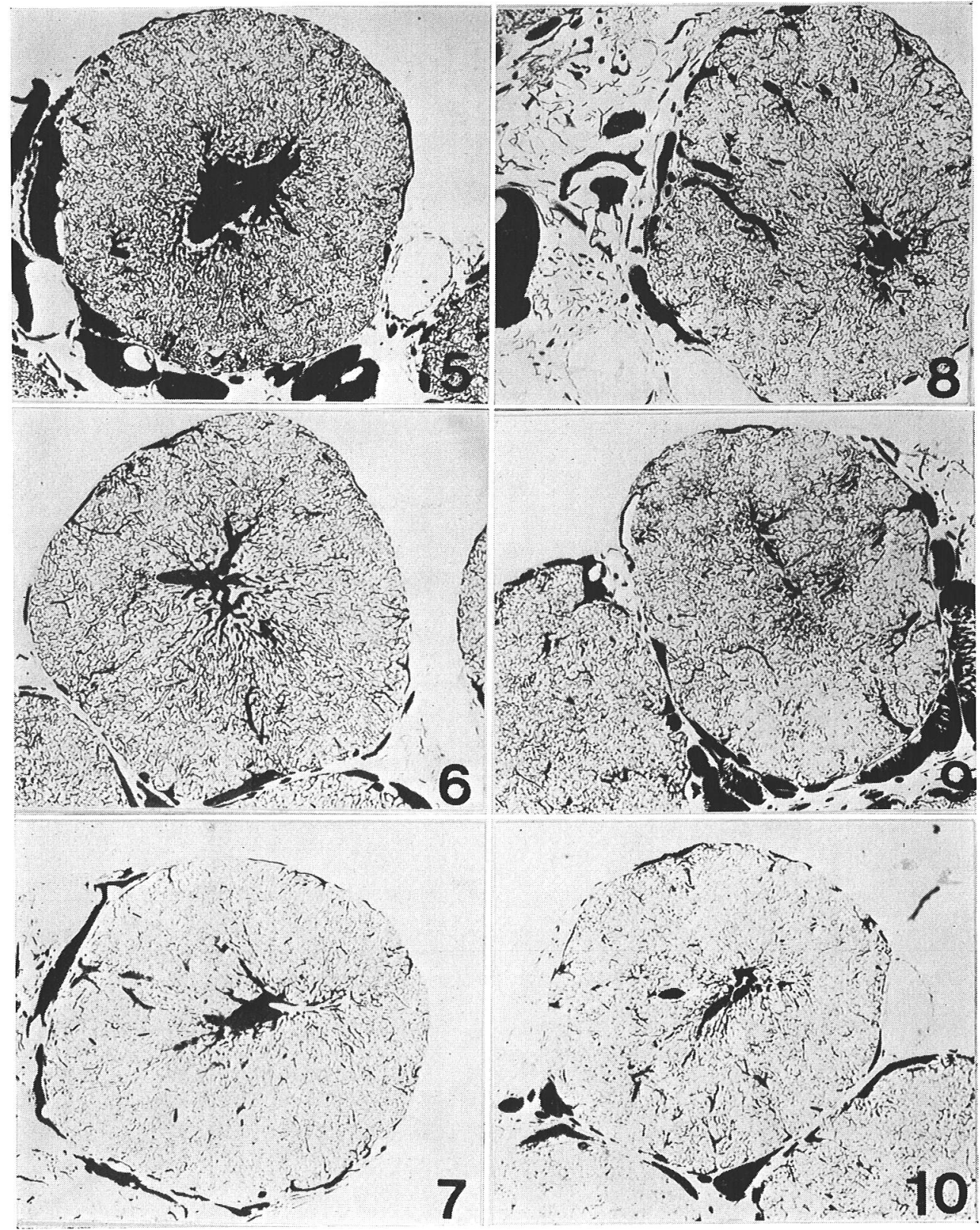

Plate II. Effect of prostaglandin $\mathrm{F}_{2 \alpha}\left(\mathrm{PGF}_{2 \alpha}\right)$ and noradrenaline (NA) on luteal microvasculature.
No. 5 Control
$(+\#)$
No. $8 \quad \mathrm{PGF}_{2 \alpha} \quad 50 \mu \mathrm{g} / \mathrm{kg}(+)$
No. 6 NA $10 \mu \mathrm{g} / \mathrm{kg}$ (\#)
No. $9 \quad \mathrm{PGF}_{2 \alpha} 125 \mu \mathrm{g} / \mathrm{kg}(+)$
No. 7 NA
$50 \mu \mathrm{g} / \mathrm{kg}( \pm)$
No. $10 \quad \mathrm{PGF}_{2 \alpha} 250 \mu \mathrm{g} / \mathrm{kg}( \pm)$ 